\title{
DYNAMICS AND DIRECTIONS \\ OF LOCAL CHANGES IN THE TOURIST FUNCTION IN LUBLIN VOIVODESHIP IN THE YEARS 2000-2015
}

\author{
RENATA KRUKOWSKA, ${ }^{1}$ ANDRZEJ ŚWIECA ${ }^{2}$
}

Maria Curie-Sklodowska University

Faculty of Earth Sciences and Spatial Management

1 e-mail: renata.krukowska@umcs.pl

2 e-mail: andrzej.swieca@poczta.umcs.lublin.pl

JEL CODES

KEYWORDS

ABSTRACT
C43, L83, O18

tourist function, accommodation, tourist traffic, Lublin voivodeship

Tourism development in an area may be assessed, inter alia, on the basis of tourist function indices determined on the premise of the capacity of the accommodation sector and the occupancy rate recorded. The subject of this paper is to identify, present, and analyse the directions of changes the tourist function in the Lublin voivodeship has undergone with respect to its particular poviats. The research methods included the use of indicator methods on relevant Polish Central Statistical Office data from the years 2000 and 2015. The findings showed a time trend of the changes in the accommodation potential and tourist traffic recorded in accommodation facilities. Changes in the tourist function were estimated on this basis. Puławski, Włodawski, Janowski, and Zamojski poviats ranked highest in respect of all the tourist function indices measured (Schneider, Charvat, and Defert). They possess significant amounts of natural and cultural resources and exhibit a relatively well-developed infrastructure. Geographically, they are concentrated in three areas which cover the main tourist regions of the Lublin voivodeship.

\section{Introduction}

The tourist function is an objective gauge of the tourist areas in which tourist activity actually occurs, equipped with tourist infrastructure of varying concentration, resulting from measures aimed at tourism development (Włodarczyk, 2006). The function is mainly contingent on the amenities and resources in the area as well as the social demand for various forms of tourism. 
The tourist function is developing if tourist traffic may be observed, followed by an increase in accommodation (Fischbach, 1989).

In view of the fact that a geographical area is used both by tourists and by business entities typical of a given region, there is certain individuality to tourist function that may be observed in particular areas (Jędrzejczyk, 1995). On the assumption that tourist function is universal (Matczak, 1989), every territorial unit of a country (voivodeship, poviat) may be characterized in respect of the intensity level of the tourist function and its course in time (Majewska, 2011).

In order to identify and determine the level of tourist function development in a given area, multiple methods and measures are employed, selected in line with the concept whereby tourist function is generated by tourist traffic and its increasing intensity, which in turn stimulates the development of services aimed at tourists (Kurek, Mika, 2007). A broad overview of relevant literature is presented in the works of J. Fischbach (1989), M. Derek (2008), G. Gołembski (2011) and A.R. Szromek (2012).

The subject of this paper is to identify, present, and analyse the directions of changes the tourist function in the Lublin voivodeship has undergone with respect to its particular territorial units at poviat level.

\section{Material and methods}

Two features were selected for the research procedure aimed at determining the tourist function, i.e. the size of accommodation sector and the type of accommodation, as well as the intensity of tourist traffic. An essential element of infrastructure which caters for tourists' basic needs, accommodation refers to the area capacity, i.e. its ability to host a certain number of tourists and successfully meet their needs (Pawlikowska-Piechotka, 2009). The intensity of tourist traffic determines the role of tourism in the economic system of the region. The larger the tourist traffic, the faster the tourist function develops (Kurek, Mika, 2007).

The current status of the tourist function, as well as the dynamics and the direction of changes therein in the Lublin voivodeship and its poviats was assessed by means of indicator methods. Tourism infrastructure level and tourist traffic intensity indicators were determined within the scope of the analyses.

The first group of indicators included the Baretje-Defert index (which stands for the number of tourist lodging establishments per 100 permanent residents of the area) and the density of tourist accommodation (which stands for the number of tourist lodging establishments per $1 \mathrm{~km}^{2}$ of the area). The second group of indicators included the Schneider index (expressing the number of accommodation users per 100 residents), the Charvat index (expressing the bed occupancy rate per 100 inhabitants) and Defert index (expressing the number of persons using lodging per $1 \mathrm{~km}^{2}$ of the area).

These indicators have been commonly used in research on the tourist function, inter alia by J. Warszyńska (1985) and A.R. Szromek (2012). The issue of changes' dynamics and directions with respect to the tourist function in Greater Poland voivodeship was analysed by A. Spychała and 
S. Graja-Zwolińska (2011) over the years 1995-2009. The development level of the tourist function as a factor stimulating urban development in Świętokrzyskie voivodeship was the subject of a study conducted by I. Kiniorska and S. Partyka (2017). An analysis of the geographical diversity of the tourist function in rural areas of Pomorskie voivodeship was performed by M. Durydiwka (2015).

This paper presents an analysis carried out on statistical data from the records of the Polish Central Statistical Office of 2000 and 2015. The values obtained were compiled into a summary of poviats, arranged by means of the ranking method from the most to the least dynamically changing in terms of their tourist function.

\section{Outcomes}

\section{Concentration level of accommodation in the Lublin voivodeship}

The tourist accommodation sector in the Lublin voivodeship is rather small in terms of size. Considering the number of lodging establishments, the Lublin voivodeship ranks $10^{\text {th }}$ nationwide (3.7\%) (Krukowska, Świeca, 2018), whereas it accounts for only 3.1\% in respect of bed places, attaining a highly unsatisfactory $12^{\text {th }}$ rank.

According to the statistical data of the Polish Central Statistical Office of the year 2015, there were 21,848 bed places spread over 369 lodging establishments in the Lublin voivodeship. Bed places included 240 objects and 14,710 places operating the whole year, which represents $65 \%$ and $67 \%$ of the voivodeship's potential respectively (Tables 1,2 ).

Table 1. Basic data regarding accommodation objects and their use in the Lublin voivodeship in 2000 and 2015

\begin{tabular}{|c|c|c|c|c|c|}
\hline Poviats & Year & Number of objects & $\begin{array}{c}\text { Number of bed } \\
\text { places }\end{array}$ & Number of users & $\begin{array}{c}\text { Number of nights } \\
\text { spent }\end{array}$ \\
\hline 1 & 2 & 3 & 4 & 5 & 6 \\
\hline \multirow{2}{*}{ Lublin voivodeship } & 2015 & 369 & 21,848 & 794,409 & $1,711,623$ \\
\hline & 2000 & 476 & 24,312 & 516,259 & $1,489,002$ \\
\hline \multirow{2}{*}{ Lublin } & 2015 & 34 & 2,874 & 221,048 & 347,609 \\
\hline & 2000 & 21 & 2,748 & 130,300 & 312,043 \\
\hline \multirow{2}{*}{ Lubelski } & 2015 & 19 & 613 & 30,886 & 41,663 \\
\hline & 2000 & 6 & 101 & 4,067 & 6,873 \\
\hline \multirow{2}{*}{ Zamość } & 2015 & 17 & 1,515 & 59,011 & 103,233 \\
\hline & 2000 & 15 & 807 & 35,827 & 68,116 \\
\hline \multirow{2}{*}{ Zamojski } & 2015 & 42 & 1,835 & 39,881 & 112,296 \\
\hline & 2000 & 66 & 2,310 & 33,462 & 97,786 \\
\hline \multirow{2}{*}{ Chełm } & 2015 & 7 & 467 & 18,008 & 37,157 \\
\hline & 2000 & 9 & 508 & 17,140 & 31,003 \\
\hline \multirow{2}{*}{ Chełmski } & 2015 & 6 & 398 & 7,329 & 7,932 \\
\hline & 2000 & 20 & 579 & 8,413 & 14,663 \\
\hline \multirow{2}{*}{ Biała Podlaska } & 2015 & 9 & 635 & 29,788 & 33,404 \\
\hline & 2000 & 12 & 373 & 17,646 & 27,421 \\
\hline \multirow{2}{*}{ Bialski } & 2015 & 25 & 1,003 & 48,963 & 61,793 \\
\hline & 2000 & 26 & 598 & 16,008 & 22,444 \\
\hline
\end{tabular}




\begin{tabular}{|c|c|c|c|c|c|}
\hline 1 & 2 & 3 & 4 & 5 & 6 \\
\hline \multirow{2}{*}{ Biłgorajski } & 2015 & 11 & 363 & 6,223 & 17,377 \\
\hline & 2000 & 14 & 529 & 4,989 & 15,475 \\
\hline \multirow{2}{*}{ Hrubieszowski } & 2015 & 7 & 254 & 6,185 & 8,277 \\
\hline & 2000 & 14 & 112 & 2,239 & 3,159 \\
\hline \multirow{2}{*}{ Janowski } & 2015 & 9 & 730 & 26,217 & 49,163 \\
\hline & 2000 & 9 & 872 & 12,871 & 34,980 \\
\hline \multirow{2}{*}{ Krasnostawski } & 2015 & 6 & 147 & 6,161 & 8,431 \\
\hline & 2000 & 8 & 250 & 5,075 & 10,583 \\
\hline \multirow{2}{*}{ Kraśnicki } & 2015 & 3 & 93 & 5,765 & 7,461 \\
\hline & 2000 & 2 & 61 & 8,312 & 8,684 \\
\hline \multirow{2}{*}{ Lubartowski } & 2015 & 16 & 1,392 & 12,105 & 43,000 \\
\hline & 2000 & 25 & 3,082 & 13,987 & 62,103 \\
\hline \multirow{2}{*}{ Łęczyński } & 2015 & 7 & 437 & 3,124 & 8,949 \\
\hline & 2000 & 11 & 555 & 1,511 & 9,558 \\
\hline \multirow{2}{*}{ Łukowski } & 2015 & 5 & 185 & 8,673 & 13,978 \\
\hline & 2000 & 9 & 581 & 6,606 & 48,339 \\
\hline \multirow{2}{*}{ Opolski } & 2015 & 7 & 251 & 6,176 & 9,801 \\
\hline & 2000 & 2 & 121 & 811 & 4,169 \\
\hline \multirow{2}{*}{ Parczewski } & 2015 & 9 & 633 & 7,972 & 18,834 \\
\hline & 2000 & 21 & 1,147 & 11,143 & 33,029 \\
\hline \multirow{2}{*}{ Puławski } & 2015 & 63 & 4,269 & 166,595 & 585,231 \\
\hline & 2000 & 40 & 2,852 & 124,306 & 428,629 \\
\hline \multirow{2}{*}{ Radzyński } & 2015 & 5 & 102 & 4,013 & 4,949 \\
\hline & 2000 & 9 & 132 & 4,115 & 4,808 \\
\hline \multirow{2}{*}{ Rycki } & 2015 & 5 & 171 & 9,140 & 14,110 \\
\hline & 2000 & 0 & 0 & 0 & 0 \\
\hline \multirow{2}{*}{ Świdnicki } & 2015 & 5 & 287 & 10,968 & 20,405 \\
\hline & 2000 & 2 & 91 & 3,306 & 7,201 \\
\hline \multirow{2}{*}{ Tomaszowski } & 2015 & 15 & 899 & 27,936 & 54,093 \\
\hline & 2000 & 38 & 1,194 & 26,546 & 62,514 \\
\hline \multirow{2}{*}{ Włodawski } & 2015 & 37 & 2,295 & 32,242 & 102,477 \\
\hline & 2000 & 97 & 4,709 & 27,509 & 175,422 \\
\hline
\end{tabular}

Source: Local Data Bank. Retrieved from: http://stat.gov.pl/bdl.

The Puławski poviat distinguished itself (Figure 1) both in terms of the number of objects and bed places in the voivodeship, with its 63 establishments providing 4,269 bed places in total recorded in the area, most of which are all-year objects and bed places (53 all-year objects constitute $84 \%$ of all objects, while 4,132 places constitute $97 \%$ of all) (Table 1, Table 2). A substantial share of the voivodeship's potential is also noted in the Zamojski (42 objects; 1,835 beds), Włodawski (37 and 2,295 respectively) and Lublin township poviat as the voivodeship capital (34 and 2,874 respectively) (Figure 1, Table 1).

In four poviats (Puławski, Zamojski, Włodawski, and Lublin) there are 176 objects and 11,273 bed places in total. These poviats, comprising $17 \%$ of the region's area, are inhabited by $28 \%$ of the total population, and they contain $48 \%$ of the regional potential as to objects and up to $52 \%$ as to bed places. Their distribution structure also indicates that in many areas of the Lublin region 
accommodation services are scarce, in particular in the Kraśnicki, Radzyński, Rycki, Łukowski, and Krasnostawski poviats (Figure 1). The number of bed places in total does not exceed 200 altogether (Table 1).

Table 2. Accommodation structure in 2015

\begin{tabular}{|c|c|c|c|c|c|c|}
\hline \multirow[b]{2}{*}{ Poviats } & \multicolumn{3}{|c|}{ Number of objects } & \multicolumn{3}{|c|}{ Number of bed places } \\
\hline & total & $\begin{array}{c}\text { of which } \\
\text { all-year objects }\end{array}$ & $\begin{array}{c}\text { of which hotel } \\
\text { objects }\end{array}$ & total & $\begin{array}{c}\text { of which } \\
\text { all-year objects }\end{array}$ & $\begin{array}{c}\text { of which hotel } \\
\text { objects }\end{array}$ \\
\hline Lublin voivodeship & 369 & 240 & 149 & 21,848 & 14,710 & 8,634 \\
\hline Lublin & 34 & 32 & 27 & 2,874 & 2,669 & 2,486 \\
\hline Lubelski & 19 & 18 & 10 & 613 & 595 & 383 \\
\hline Zamość & 17 & 14 & 12 & 1,515 & 1,080 & 770 \\
\hline Zamojski & 42 & 17 & 6 & 1,835 & 1,048 & 319 \\
\hline Chełm & 7 & 7 & 4 & 467 & 467 & 323 \\
\hline Chełmski & 6 & 3 & 2 & 398 & 153 & 130 \\
\hline Biała Podlaska & 9 & 9 & 6 & 635 & 635 & 257 \\
\hline Bialski & 25 & 17 & 9 & 1,003 & 686 & 449 \\
\hline Biłgorajski & 11 & 7 & 5 & 363 & 238 & 207 \\
\hline Hrubieszowski & 7 & 5 & 4 & 254 & 225 & 158 \\
\hline Janowski & 9 & 5 & 4 & 730 & 365 & 267 \\
\hline Krasnostawski & 6 & 5 & 4 & 147 & 137 & 121 \\
\hline Kraśnicki & 3 & 3 & 1 & 93 & 93 & 38 \\
\hline Lubartowski & 16 & 7 & 5 & 1,392 & 288 & 143 \\
\hline Łęczyński & 7 & 2 & 1 & 437 & 166 & 72 \\
\hline Łukowski & 5 & 2 & 2 & 185 & 115 & 115 \\
\hline Opolski & 7 & 6 & 5 & 251 & 226 & 178 \\
\hline Parczewski & 9 & 3 & 2 & 633 & 114 & 98 \\
\hline Puławski & 63 & 53 & 21 & 4,269 & 4,132 & 1,198 \\
\hline Radzyński & 5 & 4 & 2 & 102 & 87 & 40 \\
\hline Rycki & 5 & 4 & 5 & 171 & 159 & 171 \\
\hline Świdnicki & 5 & 5 & 4 & 287 & 287 & 229 \\
\hline Tomaszowski & 15 & 6 & 5 & 899 & 301 & 254 \\
\hline Włodawski & 37 & 6 & 3 & 2,295 & 444 & 228 \\
\hline
\end{tabular}

Source: Local Data Bank. Retrieved from: http://stat.gov.pl/bdl.

An analysis of the development dynamics of the accommodation sector in the Lublin voivodeship over the years 2000-2015 (Table 1) shows a reduction in the number of collective accommodation by $23 \%$ and by $10 \%$ in bed places. The number of bed places decreased in 12 poviats. A drop to $25 \%$ was noted in Chełm and the Janowski, Zamojski, Łęczyński, Radzyński, and Tomaszowski poviats. The most remarkable change dynamics towards a reduced potential of bed places was reported in the Lubartowski (55\%) and Lukowski (68\%) poviats. The remaining 10 poviats saw an increase in the bed place capacity. A relatively small one (to 20\%) was noted in Lublin and Włodawski poviat, a slightly larger (50-130\%) in Puławski, Kraśnicki, Bialski, Opolski and Hrubieszowski poviats, as well as in Biała Podlaska and Zamość, whereas the fastest growth (over $200 \%$ ) was reported in the Świdnicki and Lubelski poviats (Table 1). 


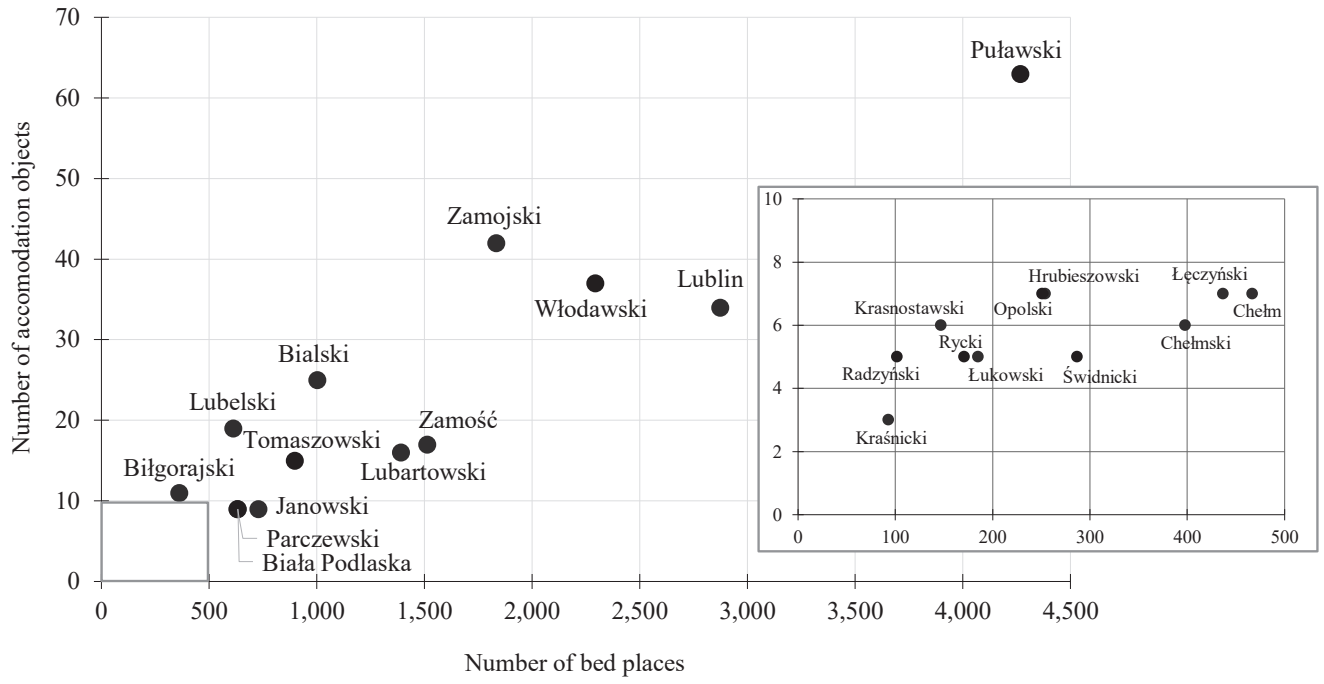

Figure 1. Number of accommodation objects and bed places in poviats of Lublin voivodeship in 2015

Soure: own elaboration.

Changes in accommodation are reflected in the Baretje-Defert index and in the accommodation density index (Table 3).

Table 3. Indicators of tourist function in the Lublin voivodeship in 2000 and 2015

\begin{tabular}{|c|c|c|c|c|c|c|}
\hline Poviats & Year & Baretje'a-Deferta & $\begin{array}{l}\text { Accommodation } \\
\text { density }\end{array}$ & Schneidera & Charvata & Deferta \\
\hline 1 & 2 & 3 & 4 & 5 & 6 & 7 \\
\hline \multirow{2}{*}{ Lublin voivodeship } & 2015 & 1.02 & 0.87 & 37.13 & 79.99 & 31.62 \\
\hline & 2000 & 1.09 & 0.97 & 23.13 & 66.71 & 20.56 \\
\hline \multirow{2}{*}{ Lublin } & 2015 & 0.84 & 19.48 & 64.88 & 102.02 & $1,498.63$ \\
\hline & 2000 & 0.77 & 18.63 & 36.62 & 87.70 & 883.39 \\
\hline \multirow{2}{*}{ Lubelski } & 2015 & 0.40 & 0.36 & 20.43 & 27.56 & 18.39 \\
\hline & 2000 & 0.07 & 0.06 & 3.00 & 5.06 & 2.42 \\
\hline \multirow{2}{*}{ Zamość } & 2015 & 2.34 & 50.00 & 91.08 & 159.34 & $1,947.56$ \\
\hline & 2000 & 1.17 & 26.46 & 52.14 & 99.12 & $1,174.66$ \\
\hline \multirow{2}{*}{ Zamojski } & 2015 & 1.69 & 0.98 & 36.79 & 103.60 & 21.32 \\
\hline & 2000 & 2.06 & 1.23 & 29.80 & 87.13 & 17.87 \\
\hline \multirow{2}{*}{ Chełm } & 2015 & 0.73 & 13.23 & 28.02 & 57.81 & 510.14 \\
\hline & 2000 & 0.72 & 14.39 & 24.21 & 43.79 & 485.55 \\
\hline \multirow{2}{*}{ Chełmski } & 2015 & 0.50 & 0.21 & 9.23 & 9.99 & 3.89 \\
\hline & 2000 & 0.76 & 0.32 & 11.11 & 19.37 & 4.72 \\
\hline \multirow{2}{*}{ Biała Podlaska } & 2015 & 1.11 & 12.85 & 51.88 & 58.18 & 603.00 \\
\hline & 2000 & 0.63 & 7.55 & 29.93 & 46.51 & 357.21 \\
\hline \multirow{2}{*}{ Bialski } & 2015 & 0.89 & 0.36 & 43.52 & 54.92 & 17.78 \\
\hline & 2000 & 0.51 & 0.22 & 13.65 & 19.14 & 5.81 \\
\hline
\end{tabular}




\begin{tabular}{|c|c|c|c|c|c|c|}
\hline 1 & 2 & 3 & 4 & 5 & 6 & 7 \\
\hline \multirow{2}{*}{ Biłgorajski } & 2015 & 0.35 & 0.22 & 6.06 & 16.93 & 3.70 \\
\hline & 2000 & 0.50 & 0.32 & 4.70 & 14.57 & 2.97 \\
\hline \multirow{2}{*}{ Hrubieszowski } & 2015 & 0.38 & 0.20 & 9.38 & 12.55 & 4.88 \\
\hline & 2000 & 0.15 & 0.09 & 3.03 & 4.27 & 1.76 \\
\hline \multirow{2}{*}{ Janowski } & 2015 & 1.56 & 0.83 & 55.91 & 104.84 & 29.95 \\
\hline & 2000 & 1.75 & 1.00 & 25.86 & 70.29 & 14.71 \\
\hline \multirow{2}{*}{ Krasnostawski } & 2015 & 0.22 & 0.14 & 9.42 & 12.89 & 5.97 \\
\hline & 2000 & 0.31 & 0.22 & 6.30 & 13.13 & 4.46 \\
\hline \multirow{2}{*}{ Kraśnicki } & 2015 & 0.10 & 0.09 & 5.91 & 7.65 & 5.73 \\
\hline & 2000 & 0.06 & 0.06 & 8.09 & 8.45 & 8.27 \\
\hline \multirow{2}{*}{ Lubartowski } & 2015 & 1.55 & 1.08 & 13.52 & 48.04 & 9.39 \\
\hline & 2000 & 3.33 & 2.39 & 15.10 & 67.02 & 10.84 \\
\hline \multirow{2}{*}{ Łęczyński } & 2015 & 0.76 & 0.69 & 5.44 & 15.59 & 4.91 \\
\hline & 2000 & 0.96 & 0.88 & 2.62 & 16.57 & 2.38 \\
\hline \multirow{2}{*}{ Łukowski } & 2015 & 0.17 & 0.13 & 7.99 & 12.87 & 6.22 \\
\hline & 2000 & 0.52 & 0.42 & 5.95 & 43.53 & 4.74 \\
\hline \multirow{2}{*}{ Opolski } & 2015 & 0.41 & 0.31 & 10.13 & 16.08 & 7.62 \\
\hline & 2000 & 0.18 & 0.15 & 1.34 & 6.36 & 1.10 \\
\hline \multirow{2}{*}{ Parczewski } & 2015 & 1.78 & 0.66 & 22.38 & 52.86 & 8.37 \\
\hline & 2000 & 2.96 & 1.20 & 28.81 & 85.41 & 11.10 \\
\hline \multirow{2}{*}{ Puławski } & 2015 & 3.71 & 4.57 & 144.61 & 507.99 & 178.35 \\
\hline & 2000 & 2.32 & 3.06 & 101.28 & 349.24 & 133.23 \\
\hline \multirow{2}{*}{ Radzyński } & 2015 & 0.17 & 0.11 & 6.66 & 8.21 & 4.16 \\
\hline & 2000 & 0.21 & 0.14 & 6.46 & 7.54 & 4.26 \\
\hline \multirow{2}{*}{ Rycki } & 2015 & 0.30 & 0.28 & 15.93 & 24.59 & 14.87 \\
\hline & 2000 & - & - & - & - & - \\
\hline \multirow{2}{*}{ Świdnicki } & 2015 & 0.40 & 0.61 & 15.10 & 28.09 & 23.42 \\
\hline & 2000 & 0.12 & 0.19 & 4.49 & 9.78 & 7.05 \\
\hline \multirow{2}{*}{ Tomaszowski } & 2015 & 1.05 & 0.60 & 32.60 & 63.12 & 18.76 \\
\hline & 2000 & 1.29 & 0.80 & 28.73 & 67.66 & 17.85 \\
\hline \multirow{2}{*}{ Włodawski } & 2015 & 5.84 & 1.83 & 82.08 & 260.89 & 25.66 \\
\hline & 2000 & 11.10 & 3.75 & 64.86 & 413.62 & 21.90 \\
\hline
\end{tabular}

Source: own study based on the Local Data Bank. Retrieved from: http://stat.gov.pl/bdl.

As to the number of inhabitants, the Baretje-Defert index shows that the value ranges in the poviats analysed were almost 30 times apart (5.8 bed places per 100 inhabitants in the Włodawski poviat vs. 0.2 bed place in the Kraśnicki, Radzyński, and Łukowski poviats). Only in 9 poviats did the indicator exceed the average value for the Lublin voivodeship (1.0 space per 100 inhabitants). These were two township poviats (Zamość, Biała Podlaska) and seven country poviats, i.e. Włodawski, Puławski, Lubartowski, and Parczewski in the North of the voivodeship, and Zamojski, Janowski, and Tomaszowski in the South (Table 3, Figure 2A).

Over the 15 years analysed (2000-2015), the Baretje-Defert index for the Lublin voivodeship decreased by $6.4 \%$. A decrease was also reported in 12 poviats (Rycki poviat not classified), with the largest drop (by over 50\%) reported in the Lubartowski and Łukowski poviats. In the remaining 
11 poviats, an increase of the index was observed. The biggest growth occurred in the Świdnicki (233\%) and Lubelski poviat (471\%).
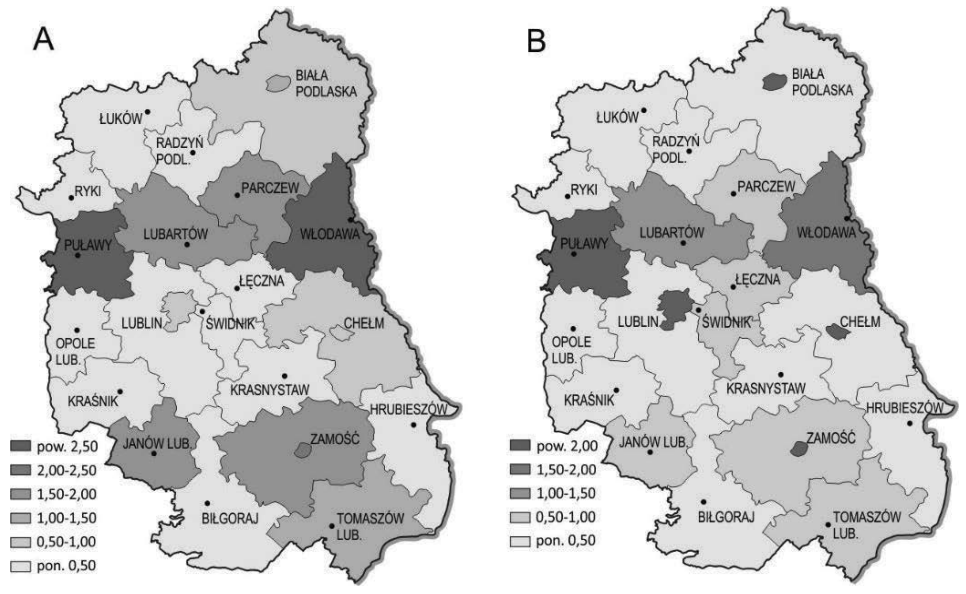

Figure 2. Spatial differentiation of Baretje-Defert (A) and accommodation density (B) in poviats of Lublin voivodeship in 2015

Source: own elaboration.

The variety is also reflected in the accommodation density. In township poviats, the differences in the value ranges are approximately fourfold between Zamość with 50 bed places per $1 \mathrm{~km}^{2}$ and Biała Podlaska with approximately 13 bed places. In the country poviats, the highest index (Puławski with about 4,6 bed places per $\mathrm{km}^{2}$ ) was 23 times higher than the lowest one (below 0.2 bed place per $1 \mathrm{~km}^{2}$ in the Kraśnicki, Radzyński, Lukowski, and Krasnostawski poviats). Eight poviats have higher indices in this respect than the voivodeship average $\left(0.9\right.$ bed place per $\left.1 \mathrm{~km}^{2}\right)$. These are Puławski, Włodawski, Lubartowski, Zamojski and Janowski country poviats, in addition to all four township poviats (Table 3, Figure 2B).

The density of accommodation also manifests the diversity and dynamics of changes (Table 3). It declined by $10 \%$ for the entire voivodeship throughout the analysed period (2000-2015). 13 poviats saw a decline in the index numerical quantity, from approximately $10 \%$ in Chełm to over $40 \%$ in the Parczewski, Włodawski, Lubartowski, and Łukowski poviats. An increase was reported in the remaining 10 poviats, below 5\% in Lublin, but from about 50 to approximately $120 \%$ in the Puławski, Kraśnicki, Bialski, Opolski, and Hrubieszowski country poviats, as well as in Biała Podlaska and in Zamość. The most dynamic growth in the accommodation density was noted in Świdnicki (by 221\%) and Lubelski (500\%) poviats. 


\section{Use of accommodation}

The use of accommodation is exhibited in the number of users and nights spent. Against the backdrop of the Polish Central Statistical Office data of 2015, the Lublin voivodeship ranked 12th among all Polish voivodeships in terms of these values. In both cases, the voivodeship's share amounted approximately to 2-3\% (Krukowska, Świeca, 2018). In 2015, lodging establishments in the Lublin voivodeship accommodated approximately 795,000 visitors, $74 \%$ of whom $(587,000)$ were hosted in hotel buildings. According to the Polish Central Statistical Office, this type of accommodation in the region is provided by 149 objects which offer 8,634 bed places. This comprises $40 \%$ of the voivodeship's accommodation capacity (Table 2 ).

There is a significant geographical differentiation in the distribution of the use of accommodation in the Lublin region. The largest concentration is exhibited by Lublin and the Puławski poviat, where tourist lodgings accommodated 221,000 and 167,000 people respectively in 2015 (about 49\% of the total accommodation users in the voivodeship). Several times fewer numbers of accommodation users, i.e. approximately 60-30,000, were reported in Zamość and Bialski, Zamojski, Włodawski, and Lubelski poviats (Table 1).

According to the data of the Polish Central Statistical Office, approximately 1,712,000 nights were spent in various tourist lodgings in the Lublin voivodeship in 2015, including 880,000 (51\%) in hotels. At the regional level, the largest number of nights spent $(585,000)$ was reported in the Puławski poviat. A relatively large quantity $(347,600)$ of nights were spent in Lublin. Zamojski, Zamość and Włodawski poviats also ranked high, as each of them had over 100,000 nights spent.

An analysis of the tourism development dynamics in the Lublin voivodeship over the years 2000 to 2015 revealed an increase trend both in the number of persons accommodated and nights spent (Table 1). In 2015, the number of accommodation users increased by $54 \%$ in relation to the year 2000 . The growth dynamics of nights spent was lower, amounting to $14.9 \%$.

\section{Level and trends of change in the tourist function}

The assessment of the tourist function in the poviats of the Lublin voivodeship is relative. The trends in the tourist function development in the poviats of the Lublin voivodeship were determined on the basis of Schneider, Charvat and Defert tourism development indices, calculated from relevant data from the years 2000 and 2015.

In 2000, the Schneider index for the Lublin voivodeship was around 23. By 2015, it increased more than 1.5 times and reached 37 (Table 3). The highest intensity of tourist traffic that year, measured by means of Schneider index, was reported in the Puławski poviat (145), whereas the lowest one (5) in the Łęczyński poviat. The Schneider index was above the voivodeship average in six other poviats, including three township poviats, i.e. Zamość (91), Lublin (65), and Biała Podlaska (52), as well as in the three country poviats, i.e. Włodawski (82), Janowski (56), and Bialski (44). The remaining poviats showed lower index values (Table, Figure 3). 

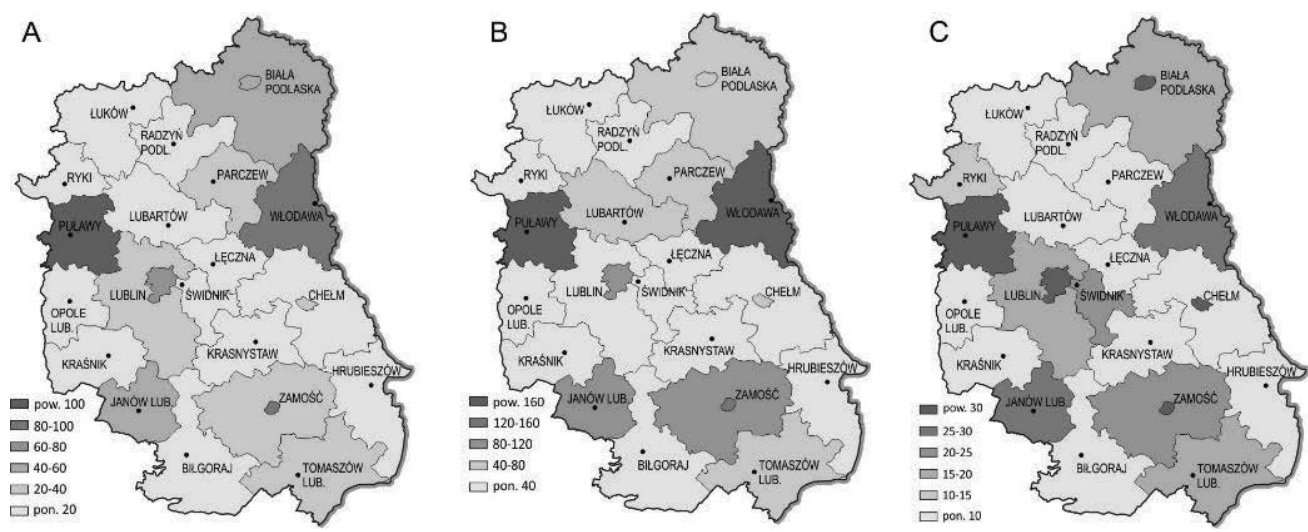

Figure 3. Spatial differentiation of Schneider (A), Charvat (B) and Defert (C) tourism development indices in poviats of Lublin voivodeship in 2015

Soure: own elaboration.

An analysis of the number of accommodation users in 2000 and 2015, along with the Schneider indices calculated therefore, reflect an increase in tourist traffic in the region of Lublin. In the years 2000-2015, the Schneider index for the Lublin voivodeship increased by approximately $60 \%$ and was observed in nineteen individual poviats. The growth was diversified, with its rate amounting to over $200 \%$ in the Hrubieszowski, Bialski, Świdnicki, Lubelski, and Opolski poviats, however, not exceeding $20 \%$ in the Radzyński poviat (Figure 3A).

The number of nights spent in relation to the number of residents, i.e. Charvat parameter, also display the current status of the tourist function and allows for the determination of its change dynamics and direction. The average Charvat index in the Lublin voivodeship in 2000 was at the level of 67, to reach ca. 80 in 2015 (Table 3). That year, it ranged from 8 in the Kraśnicki poviat up to 508 in the Puławski poviat. It exceeded the average value in six poviats, including two township poviats, i.e. Lublin (102) and Zamość (159), and four country poviats, i.e. Zamojski (104), Janowski (105), Włodawski (261), and Puławski (508). Index values were lower than the average in the remaining 18 poviats (Table 3, Figure 3B).

The Charvat index for the Lublin voivodeship increased approximately by $20 \%$ over the $15-$ year period analysed. In 2015, 14 poviats demonstrated an increase compared to the year 2000, whereas nine poviats showed a decline. A relatively high growth dynamics (100-200\%) was observed in the following poviats: Opolski (153), Bialski (187), Świdnicki (187), and Hrubieszowski (191). The largest increase (by 445\%), however, was noted in the Lubelski poviat. Taking into consideration the index value, a significant negative change in the tourist traffic was observed in the lake district of the Lublin voivodeship. For the Lubartowski, Włodawski, Parczewski, Chełmski, and Lukowski poviats, the Charvat index was lower by 30 to $70 \%$ in 2015 compared to the year 2000. 
The third from the indices analysed, the Defert index, reflects the level of tourist traffic intensity. In 2000, it was about 21 for the Lublin voivodeship, to reach 32 in 2015 (Table 3). Its value that year amounted from 4 in the Biłgorajski poviat to 1,948 in Zamość. It exceeded the average value in the remaining township poviats, i.e. Lublin (1,499), Biała Podlaska (603), and Chełm (510), and in one country poviat, i.e. Puławski (178). The other nineteen poviats showed lower values of the index, with even eleven of them below 10 (Table 3, Figure 3C).

In the 15 years studied (2000-2015), the Defert index for the voivodeship rose by ca. 54\%, similarly to the Schneider index. Eighteen poviats noted an increase in the index, whereas there was a drop in five of them. The growth was of a varying nature, with a significant increase over $200 \%$ in the Bialski (206), Świdnicki (232), Opolski (593) and Lubelski (660) poviats. Among the poviats where the Defert index decreased, the largest reduction occurred in the Parczewski (29) and Kraśnicki (31) poviats.

With respect to all the tourist function indices measured (Schneider, Charvat, and Defert), the following poviats ranked highest: Puławski, Włodawski, Janowski, and Zamojski (Figure 3). These poviats possess significant amounts of natural and cultural resources and they exhibit a relatively well-developed tourist infrastructure. Geographically, they are concentrated in three areas which cover the north-western part of the Lublin Upland (the Kazimierz-Nałęczów-Pulawy "tourist triangle"), Western Polesie (Łęczna-Włodawa Lake District), the north-eastern fragment of the Sandomierz basin (Janów Forests), and Roztocze. Highly valuable natural and cultural qualities of these areas provide favourable conditions for the development of various forms of tourism. In the assessment of the attractiveness of the natural environment and cultural heritage for tourism development carried out for the Lublin voivodeship, these poviats were included in the group of the most attractive tourist areas (Świeca et al., 2012).

Among these poviats, the tourist function proved most developed in the Pulawski and Włodawski poviats. The attractiveness of the Puławski poviat results from the combination of its cultural (Kazimierz Dolny, Puławy) and natural resources (Vistula river valley, loess ravines). It should be pointed out that the high position of the Pulawski poviat in terms of the indices measured (Schneider 456; Charvat 508; Defert 178) is distinctive largely due to its health function. A wide range of services offered by "Uzdrowisko Nałęczów" health resort and other residential healthcare objects, spa and wellness centres, as well as hotels and lodging houses with spa \& wellness infrastructure in Nałęczów, Kazimierz Dolny, and Janowiec Castle provide perfect conditions for the use of groundwater, climate features (Nałęczów is the only health resort in Poland of climate spa) and phytotherapeutic potential of plants present in the area (Skowronek et al., 2015, Świeca, Skrzypek, 2015). According to the statistical data of 2015, 63 lodging establishments operated in the puławski poviat, with approximately 4,300 bed places ( $97 \%$ of which operate all year). These premises accommodated about 167 thousand people, reaching approximately 600,000 nights spent. The objects of "Uzdrowisko Nałęczów" resort host about 130,000 customers on an annual basis (Skowronek et al., 2015), which placed it in a remarkable position in relation to the entire accommodation sector of the poviat. 
The accommodation sector of the Włodawski poviat is of a different nature, as $84 \%$ of its objects and $81 \%$ of its bed places operate during the summer season exclusively (Table 2). The level of tourist function development is reflected in the following index values: Schneider 82, Charvat 261, and Defert 26. The attractiveness of the Włodawski poviat results from the water reservoirs of the Łęczna-Włodawa lake district, as well as the poviat's unique protected areas. The analysis of tourist traffic, however, indicates that the main form of tourism in the area are holiday stays at the most attractive lake in the Łęczna-Włodawa lake district, providing the best tourist infrastructure, and that is Białe Lake (Krukowska, Świeca, 2014; Świeca et al., 2014). According to the Polish Central Statistical Office reports, there were 37 objects operating in the area in 2015, offering 2,300 bed places. These premises accommodated approximately 32,500 people who spent 102,500 nights in total.

Apart from tourist attractions and natural and cultural resources, accommodation is of fundamental importance in the process of creating an area as a tourist product. The size, structure, and the quality of the accommodation sector may stimulate or hinder the creation of tourist products (Meyer et al., 2013). It should be therefore underlined that these areas do not derive solely from the "traditional" tourist attractions and features. Activities aimed at offloading the most visited places in a region give rise to the creation of new products, often very innovative in their nature. Such examples may be found in the Puławski poviat: The Trail of Iron and Blacksmith Traditions in Wojciechowie, Magic Gardens Amusement Park in Trzcianki near Janowiec, or Małopolska Vistula River Gap Geopark (Brzezińska-Wojcik, 2012; Skowronek, 2012). New objects of interest in the Włodawski poviat include the Festival of the Three Cultures in Włodawa, the kayak route in the Polesie Bug river valley, or the Polesie Horse Riding Trail (Krukowska, Krukowski, 2009).

\section{Conclusions}

Tourist function indices are some of the possible methods to assess tourism development in an area. The tourism development level in the poviats of the Lublin voivodeship is determined on the basis of the capacity of the accommodation sector and the tourist traffic intensity, calculated from the occupancy rate recorded. The analysis proves this level to be geographically diverse. The poviats which demonstrate a relatively well-developed tourist function clearly coincide with areas where major tourist attractions are located, in particular natural attractions. It can be concluded that the tourist function development in the Lublin voivodeship is to a large extent contingent on natural resources, and to a slightly smaller extent on cultural heritage attractions. The level of tourist function in the Puławski poviat is significantly influenced by the development of the health resort industry as well as spa \& wellness tourism.

The presented data concerning the accommodation sector and tourist traffic in the Lublin voivodeship demonstrate that multiple poviats rank at highly unsatisfactory positions, particularly in the context of the local authorities' ambitions regarding tourism development (stipulated in strategic documents). It is vital to stress that the modern lines of tourism development, growing competition on the tourist market, and constantly changing tourist preferences place an increasingly 
high value on tourist infrastructure, as well as on the diversity and quality of services offered. This indicates an urgent need for the development of the tourism sector and the creation of an innovative tourism product on the basis of the marketing research and tourist market.

\section{Translated by Konrad Dejko}

\section{References}

Local Data Bank. Retrieved from: http://stat.gov.pl/bdl (20.04.2018).

Brzezińska-Wójcik, T. (2012). Produkty geoturystyczne w województwie lubelskim jako przykład działań innowacyjnych, poszerzających dotychczasową ofertę turystyczną regionu. In: D. Jegorow, A. Niedużak (ed.), Wptyw sektora $B+R$ na wzrost konkurencyjności polskiej gospodarki poprzez rozwój innowacji (pp. 127-148). Chełm: Chełmskie Stowarzyszenie Rozwoju Społeczno-Gospodarczego CIVIS.

Derek, M. (2008). Funkcja turystyczna jako czynnik rozwoju lokalnego w Polsce. Warsaw: Wydział Geografii i Studiów Regionalnych UW.

Durydiwka, M. (2015). Funkcja turystyczna obszarów wiejskich w województwie pomorskim: zróżnicowanie i zmiany. Turyzm, 1 (25), 39-45.

Fischbach, J. (1989). Funkcja turystyczna jednostek przestrzennych. Acta Universitatis Lodziensis. Turyzm, 5, 7-26.

Gołembski, G. (ed.) (2011). Sposoby mierzenia i uwarunkowania rozwoju funkcji turystycznej miasta. Przykład Poznania. Poznań: Wydawnictwo Uniwersytetu Ekonomicznego w Poznaniu.

Jędrzejczyk, I. (1995). Ekologiczne uwarunkowania i funkcje turystyki. Katowice: Śląsk.

Kiniorska, I., Partyka, S. (2017). Funkcja turystyczna jako czynnik aktywizujący miasta województwa świętokrzyskiego. Ekonomiczne Problemy Turystyki, 2 (38), 157-167.

Krukowska, R., Krukowski, M. (2009). Ocena atrakcyjności turystycznej Pojezierza Łęczyńsko-Włodawskiego. Annales UMCS, sec. B, LXIV, 1, 77-96.

Krukowska, R., Świeca, A. (2014). Ocena stopnia atrakcyjności jezior i możliwości wypoczynku na Pojezierzu ŁęczyńskoWłodawskim. In: A. Hakuć-Błażowska, G. Furgała-Selezniow, A. Skrzypczak (eds.) Problemy turystyki i rekreacji wodnej (pp. 91-102). Olsztyn: Wydawnictwo Uniwersytetu Warmińsko-Mazurskiego.

Krukowska, R., Świeca, A. (2018). Tourist function as an element of voivodships' competitiveness. Polish Journal of Sport And Tourism, 2 (25).

Kurek, W., Mika, M. (2007). Turystyka jako przedmiot badań naukowych. In: W. Kurek (ed.), Turystyka (pp. 11-49). Warszawa: Wydawnictwo Naukowe PWN.

Majewska, J. (2011). Pomiar i ocena stadium rozwoju turystycznego miast w ostatnim dziesięcioleciu - Poznań na tle największych miast w Polsce. In: G. Gołembski (ed.), Sposoby mierzenia i uwarunkowania rozwoju funkcji turystycznej miasta. Przyktad Poznania (pp. 36-65). Poznań: Wydawnictwo Uniwersytetu Ekonomicznego w Poznaniu.

Matczak, A. (1989). Problemy badania funkcji turystycznej miast Polski. Acta Universitatis Lodziensis. Turyzm, 5, $27-39$.

Meyer, B., Panasiuk, A., Sawińska, A. (2013). Baza noclegowa jako determinanta kreowania produktu turystycznego „Pomorska Droga św. Jakuba” w województwie zachodniopomorskim. Ekonomiczne Problemy Turystyki, 4 (24), 131-145.

Pawlikowska-Piechotka, A. (2009). Zagospodarowanie turystyczne i rekreacyjne. Gdynia: Novae Res.

Skowronek, E. (2012). Budowanie innowacyjności oferty turystycznej województwa lubelskiego w zakresie turystyki kulturowej. D. Jegorow, A. Niedużak (ed.), Wpływ sektora B $R$ na wzrost konkurencyjności polskiej gospodarki poprzez rozwój innowacji (pp. 99-126), Chełmskie Stowarzyszenie Rozwoju Społeczno-Gospodarczego CIVIS: Chełm.

Skowronek, E., Brzezińska-Wójcik, T., Harasimiuk, M., Rutkowski, T., Szeląg, K., Świeca, A., Czerniec, W. (2015). Projekt zintegrowanego produktu turystycznego „Szlak zdrowia i urody - spotkanie z naturą” w świetle geograficznych uwarunkowań Obszaru Funkcjonalnego Powiśle Lubelskie. Europa Regionum, XXIII, 119-136. 
Spychała, A., Graja-Zwolińska, S. (2011). Dynamika i kierunki zmian funkcji turystycznej województwa wielkopolskiego w latach 1995-2009. In: B. Krakowiak, J. Latosińska (eds.), Warsztaty z Geografii Turyzmu. Turystyka polska w latach 1989-2009 (pp. 81-91). Łódź: Wydawnictwo UŁ.

Szromek, A.R. (2012). Wskaźniki funkcji turystycznej. Koncepcja wskaźnika funkcji turystycznej i uzdrowiskowej. Gliwice: Wydawnictwo Politechniki Śląskiej.

Świeca, A., Brzezińska-Wójcik, T., Jóźwik, M.J., Krukowska, R., Skowronek, E., Tucki, A. (2014). Selected aspects of the tourist space of The Lublin Region (case study). Turyzm, 1 (24), 83-90.

Świeca, A., Krukowska, R., Tucki, A., Skowronek, E., Brzezińska-Wójcik, T., Kociuba, W., Jóźwik, M. (2012). Possibilities of tourist use of natural and cultural resources in the Lublin region-case study. Annales UMCS, sec. B, LXVII, 1 , 219-244.

Świeca, A., Skrzypek, B. (2015). Spa Services in hotel facilities in the Lublin province. The importance of hotel facilities in the provision of SPA services in the Lublin province. Polish Journal of Sport and Tourism, 2 (22), 118-133.

Warszyńska, J. (1985). Funkcja turystyczna Karpat polskich. Studia Geographica. Series Geographica-Oeconomica, XVIII, 79-104.

Włodarczyk, B. (2006). Przestrzeń turystyczna - cykliczność, ,aktorzy”, determinanty rozwoju. Turyzm, 2 (16), 41-64.

\section{DYNAMIKA I KIERUNKI ZMIAN FUNKCJI TURYSTYCZNEJ WOJEWÓDZTWA LUBELSKIEGO W UJECCIU LOKALNYM W LATACH 2000-2015}

\section{SŁOWA KLUCZOWE STRESZCZENIE}

funkcja turystyczna, baza noclegowa, ruch turystyczny, województwo lubelskie

Wskaźniki funkcji turystycznej, określone na podstawie wielkości bazy noclegowej oraz ewidencjonowanego w niej ruchu turystycznego, stanowią jedną z metod możliwych do zastosowania w ocenie rozwoju turystycznego obszaru. Celem poniższego opracowania jest rozpoznanie, przedstawienie i analiza kierunków zmian funkcji turystycznej województwa lubelskiego w powiatach. W postępowaniu badawczym zastosowano metody wskaźnikowe, wykorzystując odpowiednie dane z lat 2000 i 2015 zaczerpnięte z GUS. Uzyskane wyniki pozwoliły poznać czasowy trend zmian potencjału noclegowego oraz ruchu turystycznego notowanego w tych obiektach i na tej podstawie oszacowania zmian funkcji turystycznej. Wysoką pozycję w rozkładzie mierzonych wskaźników funkcji turystycznej (Schneidera, Charvata i Deferta) zajmują powiaty: puławski, włodawski, janowski i zamojski. Wyróżniają się one znaczącymi zasobami przyrodniczymi i kulturowymi oraz stosunkowo dobrze rozwiniętą infrastrukturą. Skupiają się one w trzech obszarach pokrywających się z głównymi regionami turystycznymi województwa lubelskiego. 